UDC 614.40: 615.7

DOI: $10.21668 /$ health.risk/2020.4.19.eng

Review

\title{
COVID-19: WELL-KNOWN DRUGS, NEW OPPORTUNITIES
}

\author{
A.Kh. Ashirmetov ${ }^{1}$, I.R. Mavlyanov ${ }^{2}$, Z.I. Mavlyanov ${ }^{2}$, G.Zh. Zharylkasynova ${ }^{3}$ \\ ${ }^{1}$ Uzbekistan's Public Healthcare Ministry, 26 Spitamena Str., Tashkent, 100121, Uzbekistan \\ ${ }^{2}$ Tashkent Institute for Post-Graduate Medical Education, 12 Sharafa Ave., Tashkent, 100000, Uzbekistan \\ ${ }^{3}$ Bukhara State Medical Institute named after Abu Ali ibn Sino, 1 Navoi Ave., Bukhara, 200118, Uzbekistan
}

Up to now, coronavirus infection that causes an acute respiratory syndrome has been detected almost in all countries worldwide. Global spread of SARS-CoV-2 virus has become a world pandemic and there is no efficient and commonly accepted conventional therapy against COVID-19. Due to the existing emergency most drugs that can potentially be used to treat COVID-19 are allowed to be applied only basing on certain data probing their safety and efficiency against SARS-CoV. At present only Lopinavir/Ritonavir and Remdesivir are the only anti-virus drugs that are included into well-recognized management procedures for COVID-19 treatment; an acceptable alternative could probably be combined therapy that includes Hydroxychloroquine and Azithromycin. Given the existing situation, a lot of drugs that are usually used to treat other diseases are now being suggested as probable ways to treat COVID-19 taking into account all the available knowledge on pathophysiology of the infection.

In this review, basing on available data on how SARA-CoV-2 virus enters a cell and pathophysiological aspects of cytokine storm development, we have strived to highlight certain prospects related to applying anti-viral medications, antiinflammatory and immune-suppressing drugs, vitamins and microelements that are widely used to treat and prevent various diseases. Most tested drugs as well as zinc preparations, and vitamins $C$ and $D_{3}$ turned out to have not only immunemodulating but also anti-inflammatory properties; or either they were able to block ways for the virus to enter a cell or disrupt SARS-CoV-2 intracellular replication.

Having leant from previous experience in fighting against SARS and MERS, doctors have applied some existing drugs to treat COVID-19 infections in their clinical practices; clinical tests aimed at confirming their safety and efficiency in treating COVID-19 are still being performed at the moment. Although a lot of various treatment procedures have been suggested, it is necessary to perform specifically planned randomized clinical trials based on evidence-based medicine principles, if we want to determine the most suitable ones.

Key words: coronavirus, SARS-CoV-2, COVID-19, anti-viral medications, immune-modulating drugs, anti-inflammatory drugs, medications, clinical tests.

Starting from severe acute respiratory syndrome (SARS-CoV) in 2002 and MiddleEast respiratory syndrome (MERS-CoV) in 2012 caused by coronaviruses, SARS-CoV-2 occurrence has become the third event when highly pathogenic and wide-scale coronavirus epidemic has spread throughout human population in the 21 st century. On January 30 , 2020 the World Health Organization (WHO) officially declared COVID-19 epidemic to be an internationally significant emergency in public healthcare $[1,2]$.

The epidemic outbreak was established to have been caused by a new virus that was different either from Middle-East respiratory syndrome coronavirus (MERS-CoV) or severe acute respiratory syndrome virus (SARS-CoV) [3, 4]. This virus belongs to RNA viruses' family called Coronaviridiae, is probably recombinant and is carried by

(C) Ashirmetov A.Kh., Mavlyanov I.R., Mavlyanov Z.I., Zharylkasynova G.Zh., 2020

Abdurashid Kh. Ashirmetov - Doctor of Medical Science, Professor, Chief expert (e-mail: rrrh@mail.ru; tel.: +9 (98974) 40-47-56; ORCID: https://orcid.org/0000-0002-1774-2911).

Iskandar R. Mavlyanov - Doctor of Medical Science, Professor, Head of the Clinical Pharmacology Department (e-mail: iskandar.mavlyanov@inbox.ru; tel.: +9 (98946) 08-78-95; ORCID: https://orcid.org/0000-0001-5470-3498).

Zafar I. Mavlyanov - Doctor of Medical Science, Associate professor at the Clinical Pharmacology Department (e-mail: iskandar.mavlyanov@inbox.ru; tel.: +9 (98951) 69-08-70; ORCID: https://orcid.org/0000-0001-6012-9613).

Gaukhar Zh. Zharylkasynova - Candidate of Medical Sciences, Vice-rector responsible for education, Associate professor at the Department of Post-Graduate studies for General Practitioners (e-mail: gavhar72@inbox.ru; tel.: +9 (98914) 48-48-26; ORCID: https://orcid.org/0000-0001-5376-3034). 
bats [5]. Recombination occurred in glycoprotein area on virus surface thorns where receptor of cell surface endocytosis was recognized, namely angiotensin-converting enzyme 2 (ACE2) [6, 7].

Accumulated data indicate that SARSCoV-2 infection can cause acute respiratory syndrome that is greatly similar to a clinical picture usually occurring in case of pneumonia developed in people suffering from autoimmune diseases (that is, rheumatoid arthritis (RA), systemic lupus erythematosus (SLE), systemic sclerosis, and eosinophilic granulomatosis with poly-vasculitis), and auto-inflammatory diseases (for example, systemic idiopathic arthritis etc.) [8-10].

COVID-19 disease occurrence was related to full-blown anti-inflammatory status which was very similar to cytokine storm and involved producing and maintaining high contents of various cytokines including interleukins (IL)-1 $\beta$, IL-1R $\alpha$, IL-2, IL-10, fibroblast growth factor (FGF), granulocytemacrophage colony-stimulating factor (GM$\mathrm{CSF})$, granulocyte colony-stimulating factor (G-CSF), interferon gamma-induced protein 10 (IP10), monocytes chemoattractant protein 1 (MCP1), macrophage anti-inflammatory protein 1 alpha (MIP1A), plateletderived growth factor (PDGF), tumor necrosis factor alpha (TNF $\alpha)$, and vascular endothelium growth factor (VEGF) [11, 12]. Patients who are in critical state suffer from a drastic increase in contents of these factors, and IL- 6 concentrations correlate with an increased in mortality $[13,14]$.

At present there are no standard procedures for treating COVID-19. Bearing in mind that the virus has a unique structure and the disease has different pathogenesis, it is necessary to develop COVID-19-specific treatment procedures, especially vaccines and antiviral medications. However, new vaccines development according to international standards will require not less than 18 months. As for new antiviral medications, it is still impossible to predict when they will be created and tested despite all promising possibilities available in the field. Given that, it is quite obvious that when the epidemic is at its peak, it is necessary to look for other solutions. Therefore, there has been an opinion that certain research works that could really make for finding these solutions should be aimed at developing and suggesting medications with their therapeutic properties being well-known from previous examinations, both traditional and non-traditional ones, that focused on studying other diseases with similar pathogenetic mechanisms. Bearing in mind that the epidemic is spreading rapidly and complications caused by it are rather severe, at present doctors who are treating infected patients need as much available therapeutic alternatives as it is only possible. This emergency the scientific society has to face when searching for ways to overcome COVID-19 pandemic calls for necessity to use medications that have not been properly approved as their usability for treating COVID-19 infections has only preliminary scientific justification.

When it comes to antiviral medications, experts have chosen to turn to previous experience gained in overcoming SARS and MERS; there are clinical tests being performed at the moment with their focus on estimating efficiency and safety of these existing medications when they are applied to treat COVID-19 [15]. In particular, bearing in mind that there are certain similarities between SARS-CoV-2 and other beta-coronavirus associated with such past epidemics as SARS-CoV and MERS-CoV experts took the same medications that had been used to treat them and yielded contradictory results (interferon, ribavirin, and lopinavir/ritonavir) and considered them as tool for treating COVID-19 [16, 17]. But it turned out that antiviral medications and systemic therapy with corticosteroids that was earlier applied in clinical practices, including neuraminidase inhibitors (oseltamivir, peramivir, zanamivir, etc.) as well as ganciclovir, acyclovir, and 
ribavirin used to eliminate flu virus, were not efficient for treating COVID-19 and were not recommended $[18,19]$.

Such protease inhibitors as lopinavir and ritonavir that were used for treating human immunodeficiency virus (HIV), MERS-CoV, and SARS-CoV turned out to be quite efficient in treating COVID-19 in South Korea $[20,21]$.

Besides, remdesivir which is now being developed as an adenosine analogue for treating Ebola infection has recently been accepted as a promising antiviral medication against a wide range of RNA viruses; it has yielded positive preliminary results in treating SARS-CoV-2 infection [22]. Remdesivir has been shown to produce effects on virus RNA-dependent RNA polymerase ( $\mathrm{rdRp}$ ); it is able to efficiently avoid correction by virus exoribonuclease and prevents RNA virus transcription from completion [23]. Since its efficiency in treating patients with SARSCoV-2 infection was estimated in March 2020, the medication has been recommended to be applied in a single oral dose equal to $200 \mathrm{mg}$ on the $1^{\text {st }}$ day with the subsequent maintaining doses equal to $100 \mathrm{mg}$ taken once a day for 3-5 days [24].

Another nucleotide analogue used to destroy $\mathrm{RdRp}$-dependent virus replication is called favipiravir; it has been approved on by research experts in several countries and has been proven to be able to make outcomes better for patients with COVID-19 [25]. As per preliminary results, favipiravir turned out to be more efficient in 80 cases than lopinavir/ritonavir and patients who took it didn't suffer from any significant adverse reactions [26].

Arbidol and arbidol mesylate have also been shown to produce significant inhibiting effects on SARS-CoV reproduction [27]. Basing on that, clinical experts combined western and Chinese treatment procedures, accordingly including lopinavir/ritonabir (Kaletra $\left.{ }^{\circledR}\right)$, arbidol, and Shufeng Jiedu Capsule (SFJDC, traditional Chinese medicine); it allowed them to achieve significant improvement of symptoms related to COVID-19 pneumonia in Shanghai Clinical Center of China Public Healthcare [28]. At present, a wide range of antiviral medications are being tested as possible tools to overcome COVID-19 infection including nitazoxanide, nafamostat, darunavir, cobicistat, emtricitabine/tenofovir, etc. [29, 30].

Apart from using certain antiviral medications, experts have also suggested a lot of other medications usually applied to treat various diseases as probable tools to treat COVID-19; these suggestions result from considerable data being accumulated on the infection pathophysiology.

Glucocorticoids play a significant role in rheumatologic clinical practices and are widely used to treat such diseases as rheumatoid arthritis (RA), systemic lupus erythematosus (SLE), vasculitis, etc. due to their immune-depressing properties [31, 32]. However, high corticosteroid doses are closely connected with such adverse effects as secondary infections and virus resistance occurrence. In accordance with the Chinese clinical guidance for COVID-19 pneumonia diagnosis and treatment (the $7^{\text {th }}$ edition) ${ }^{1}$, in China only low and moderate corticosteroid doses can be potentially useful in therapy applied to treat seriously ill patients with COVID-19 pneumonia. The preliminary guide on clinical practices for treating COVID-19 published by the WHO does not recommend using corticosteroids excluding such clinical reasons as chronic lung disease exacerbation or septic shock [33].

Chloroquine and its derivative, hydroxychloroquine, are aminoquinoline com-

\footnotetext{
${ }^{1}$ Chinese clinical guidance for COVID-19 pneumonia diagnosis and treatment (7th edition). Beijing: National Health and Family Planning Commission of China (NHPFC), 2020. Available at: http://kjfy.meetingchina.org/msite/news/ show/cn/3337.html (13.05.2020).
} 
plexes that are registered as medications for treating and preventing malaria and many other auto-immune diseases [34]. Chloroquine use as an anti-malaria medication is significantly limited nowadays to widely spread resistant malaria plasmodium, but hydroxychloroquine is now considered a vital component in primary treatment of RA and SLE due to its apparent immune-modulating effects [35].

Chloroquine can inhibit $\mathrm{pH}$-dependent stages in replication of certain viruses including significant effects produced on SARS-CoV infectious agents. Besides, it has immune-modulating effects as it inhibits TNF- $\alpha$ and IL- 6 production/release and it also acts as a new autophagy inhibitor that can prevent viruses from reproducing themselves [36]. Several research works revealed that chloroquine was able to block glycosilation of angiotensin-converting enzyme 2 (ACE-2) with an ability to inhibit SARS CoV-2 virus ability to enter cells. Preliminary results confirm that the medication can suppress COVID-19 pneumonia development thus improving a lung x-ray picture and reducing duration of the disease. Basing on this evidence, chloroquine and hydroxychloroquine were included into certain treatment procedures in China and Italy as well as in most other countries worldwide $[37,38]$.

However, experience gained via applying these medications in an actual epidemiologic situation has also revealed risks related to probable adverse effects [39, 40]. In rheumatology chloroquine and hydroxychloroquine are most widely prescribed and they are proven to have potential adverse effects such as retinopathy, cardiotoxicity, and myelotoxicity; these effects are a real threat for patients with rheumatoid arthritis and collagenosis in case the medications are taken for a long time [41]. In case there is acute COVID-19 infection, these medications can only be used for a very short period of time (5-20 days according to a recom- mended treatment procedure) with probably an insignificant risk of adverse effects [37, 38]. Nevertheless, we should remember that such acute side effects as hyper-sensitivity and gastrointestinal intolerance require special attention, especially when it comes to patients with COVID-19 who are in critical condition.

Soon we expect to get access to results obtained via clinical tests with use of the $1^{\text {st }}$ hydroxychloroquine dose equal to $400 \mathrm{mg}$ taken in the $1^{\text {st }}$ day and subsequent maintaining doses equal to $200 \mathrm{mg}$ taken for the following 4 days; it will allow clarifying whether a theoretically strong effect can be produced by the medication on survival and recovery of patients with COVID-19 [42]. Until then, the medications remain basic ones in the current treatment procedures due to their impeccable safety profiles and huge experience on their use in clinical practices.

According to a recent research work, when azithromycin was added to a treatment strategy applied to treat a patient with severe COVID-19 (500 $\mathrm{mg}$ the $1^{\text {st }}$ single dose, then $250 \mathrm{mg}$ once a day for 2-5 days), it resulted in significant growth in hydoxychloroquine efficiency (200 mg thrice a day for 10 days) [43] And at present several randomized clinical examinations are performed that involve use of such a combination to treat COVID-19 with different severity (NCT04321278, NCT04322396, NCT04322123, NCT04324463).

Non-steroid anti-inflammatory medications (NAFM) are easily available and are usually prescribed to treat pains, fever, and inflammations in case of many diseases, especially in rheumatology. Several years ago it was shown that a protein part in SARS-CoV thorn activated cyclooxigenase- 2 expression, and naproxen turned out to have a counteracting effect; besides, it was detected that ibuprofen had inhibiting effects on ACE2 $[44,45]$. It has been decided to examine naproxen efficiency when the medication is included into a standard treatment procedure for patients with COVID-19 who are in criti- 
cal conditions; clinical tests are now at their $3^{\text {rd }}$ stage [46]. But at the same tine regular symptomatic use of NAFM is still not recommended as the primary variant in basic COVID-19 treatment due to such patients running higher risks of hospitalization, critical condition, and mortality which correlates with age and concomitant diseases, especially hypertension [47].

There has been a report recently on efficiency of tocilizumab, interleukin-6 inhibitor (humanized monoclonal antibody against IL-6 receptor which is used in rheumatoid arthritis treatment) for treating patients with severe COVID-19 pneumonia [48]. A randomized clinical examination aimed at estimating tocilizumab safety and efficiency in treating COVID-19 is still going on (ChiCTR2000029765). In China it was recommended to use tocilizumab as it provided an opportunity to treat patients with extensive and bilateral pneumonia or seriously ill patients with high IL-6 contents [48].

Another interesting anti-inflammatory medication is baricitinib, cytokine production inhibitor. It inhibits JAKkinase and is licensed to treat rheumatoid arthritis; reported efficiency and safety are quite satisfactory. Use of baricitinib in treating COVID-19 can bring good results as the medication acts against a wide range of cytokines. And finally, a minimal interaction between baricitinib and relevant CYP P-450 enzymes that metabolize it makes the medication a possible option to be included into treatment procedures in a combination with anti-viral medications such as lopinavir/ritonavir and remdesivir [49].

It is known that SARS-CoV-2 enters target cells via ACE2 receptor and transmembrane protease, Serin 2 (TMPRSS2). And here TMPRSS2 inhibitors can prevent the virus from entering a cell due to blocking SARS-CoV-2 thorn protein [50]. Such effects are produced by camostat, a protease inhibitor used to treat chronic pancreatitis [51]. At present there is a randomized placebo- control examination focusing on use of this medication to treat COVID-19 (NCT04321096).

A vital task when it comes to treating COVID-19 is to block cytokine storm; very promising results were detected for dapson, a sulfone medication with anti-inflammatory effects; doxycycline, an antibiotic from tetracycline group; and promazien, a neuroleptic drug used in psychiatric practices [52-54]. There are randomized clinical examinations with participating out-patients with COVID-19 that involve use of these medications (NCT04322682) together with colchicine, anti-tumor and anti-inflammatory medication that inhibit cellular microchannel polymerization [53]. And finally, basing on data regarding produced effects, there is a clinical examination going on at the moment that focuses on efficiency of treatment with losartan for out-patients (NCT04311177) and hospitalized patients (NCT04312009) with COVID-19.

Vitamin D is known to control inborn and adaptive immunity and its deficiency is related to auto-immune reactions growth and increased susceptibility to infections; it can well play a significant role in decreasing COVID-19 risks [55, 56]. Since vitamin D deficiency is widely spread, especially among elderly people $[57,58]$ and it tends to grow in case sunshine is also in deficiency, it was probably not accidental that the $1^{\text {st }}$ SARS-Cov-2 outbreak occurred in winter season and involved high mortality among elderly people [59, 60]. In order to slow down virus replication and prevent antiinflammatory cytokine production, there are several clinical examinations being performed on patients with COVD-19 at the moment; they involve use of vitamin D3 in a dose equal to 10.0 units per day during several weeks (NCT04334005, NCT04344041) [61].

Besides, basing on clinical results obtained in COVID-19 infection focus in China, experts made an assumption that taste and smell loss could be caused by zinc deficiency as such symptoms are quite typical 
for this state $[62,63]$. Since preliminary research has revealed that zinc produces inhibiting effects on coronavirus replication, it is assumed that if a person consumes zinc in a dose equal to 50 grams a day, it can provide certain protection against COVID-19 due to a body more efficiently resisting against the viral infection. The $1^{\text {st }}$ clinical examination that involves intravenous zinc introduction into patients with COVID-19 is going on in Australia (ACTRN12620000454976). Besides, there are several clinical examinations being performed at the moment that involve use of zinc combined with other medications (that is, hydroxychloroquine, vitamin D, vitamin C) to treat COVID-19 (NCT04326725, NCT04351490, NCT04342728).

Conclusions. Therefore, we can conclude that the world is facing a new dangerous virus with higher pathogenicity than all the known infections. Over a few short months SARS-CoV-2 has spread throughout the world with menacing speed and is now threatening global and individual health and economic prosperity. At present there are no registered vaccines or standardized treatment procedures specifying certain medications and schemes for their use that are efficient against SARS-CoV-2. As it is a real emergency, most medications that can potentially treat COVID-19 are allowed to be used basing only on data on their safety and efficiency against SARS-CoV-2. At the moment only lopinavir/ritonavir and remdesivir are anti-viral medications that are included into serious treatment procedures for COVID-19 treatment; an acceptable alternative might be combined therapy with hydroxychloroquine and azithromycine. Given the existing situation and taking into account available data on the infection pathophysiology, experts have started to suggest many medications that are usually used to treat various diseases as possible treatment methods against COVID-19. We hope that clinical examinations involving use of these medications will allow obtaining high quality data; these data can be used to objectively estimate a probable therapy aimed at both treating and preventing this disease that causes a global emergency worldwide. Enhanced international cooperation and clinical examinations performed on a global level with a great number of patients participating in them should become a way for achieving valid and ultimate results.

Funding. The research was not granted any sponsor support.

Conflict of interests. The authors declare there is no any conflict of interests.

\section{References}

1. Li H., Liu S.-M., Yu X.-H., Tang C.-K. Coronavirus disease 2019 (COVID-19): current status and future perspectives. International Journal of Antimicrobial Agents, 2020, vol. 55, no. 5, pp. 105951. DOI: $10.1016 / j$.jjantimicag.2020.105951

2. Morse J.S., Lalonde T., Xu S., Liu W.R. Learning from the past: possible urgent prevention and treatment options for severe acute respiratory infections caused by $2019-\mathrm{nCoV}$. Chembiochem, 2020, vol. 21, no. 5, pp. 730-738. DOI: 10.1002/cbic.202000047

3. Zhu N., Zhang D., Wang W., Li X., Yang B., Song J., Zhao X., Huang B. [et al.]. A novel coronavirus from patients with pneumonia in China, 2019. N. Engl. J. Med., 2020, vol. 382, no. 8, pp. 727-733. DOI: 10.1056/NEJMoa2001017

4. Zhou P., Yang X., Wang X., Hu B., Zhang L., Zhang W., Si H.-R., Zhu Y. [et al.]. Discovery of a novel coronavirus associated with the recent pneumonia outbreak in humans and its potential bat origin. bioRxiv, 2020, no. 23, pp. 18. DOI: 10.1038/s41586-020-2012-7

5. Chen Y., Liu Q., Guo D. Emerging coronaviruses: genome structure, replication, and pathogenesis. J. Med. Virol., 2020, vol. 92, no. 4, pp. 418-423. DOI: 10.1002/jmv.25681

6. Hoffmann M., Kleine-Weber H., Krüger N., Müller M., Drosten C., Pöhlmann S. The novel coronavirus 2019 (2019-nCoV) uses the SARS-coronavirus receptor ACE2 and the cellular protease TMPRSS2 for entry into target cells. bioRxiv, 2020, no. 31, pp. 23. DOI: 10.1101/2020.01.31.929042 
7. Qiu T., Mao T., Wang Y., Zhou M., Qiu J., Wang J., Xu J., Cao Z. Identification of potential crossprotective epitope between 2019-nCoV and SARS virus. J. Genet. Genom., 2020, vol. 20, no. 47 (2), pp. 115-117. DOI: $10.1016 /$ j.jgg.2020.01.003

8. Perricone C., Triggianese P., Bartoloni E., Cafaro G., Bonifacio A.F., Bursi R., Perricone R., Gerli R. The anti-viral facet of anti-rheumatic drugs: Lessons from COVID-19 Journal of Autoimmunity. Journal of Autoimmunity, 2020, vol. 111, pp. 102468. DOI: 10.1016/j.jaut.2020.102468

9. Zhang W., Zhao Y., Zhang F., Wang Q., Li T., Liu Z., Wang J., Qin Y. [et al.]. The use of antiinflammatory drugs in the treatment of people with severe coronavirus disease 2019 (COVID-19): The Perspectives of clinical immunologists from China. Clinical Immunology, 2020, no. 214, pp. 108393. DOI: $10.1016 /$ j.clim.2020.108393

10. Favallia E.G., Ingegnoli F., De Lucia O., Cincinelli G., Cima R., Caporali R. COVID-19 infection and rheumatoid arthritis: Faraway, so close! Autoimmunity Reviews, 2020, vol. 19, no. 5, pp. 102523. DOI: 10.1016/j.autrev.2020.102523

11. Geng Y.-J., Wei Z.-Y., Qian H.-Y., Huang J., Lodato R., Castriotta R.J. [et al.]. Castriotta Pathophysiological Characteristics and Therapeutic Approaches for Pulmonary Injury and Cardiovascular Complications of Coronavirus Disease 2019. Cardiovascular Pathology, 2020, no. 47, pp. 107228. DOI: $10.1016 /$ j.carpath.2020.107228

12. Mehta P., McAuley D.F., Brown M., Sanchez E., Tattersall R.S., Manson J.J., HLH Across Speciality Collaboration. COVID-19: consider cytokine storm syndromes and immunosuppression. Lancet, 2020, vol. 28, no. 395 (10229), pp. 1033-1034. DOI: 10.1016/S0140-6736 (20) 30628-0

13. Pedersen S.F., Ho Y.C. SARS-CoV-2: a storm is raging. J. Clin. Invest, 2020, vol. 1, no. 130 (5), pp. 2202-2205. DOI: 10.1172/JCI137647

14. Li G., Fan Y., Lai Y., Han T., Li Z., Zhou P., Pan P., Wang W. [et al.]. Coronavirus infections and immune responses. J. Med. Virol, 2020, vol. 92, no. 4, pp. 424-432. DOI: 10.1002/jmv.25685

15. Zumla A., Chan J.F., Azhar E.I., Hui D.S.C., Yuen K.-Y. Coronaviruses - drug discovery and therapeutic options. Nat Rev. Drug. Discov., 2016, vol. 15, no. 5, pp. 327-347. DOI: 10.1038/nrd.2015.37

16. Martinez M.A. Compounds with therapeutic potential against novel respiratory 2019 coronavirus. Antimicrob Agents Chemother, 2020, vol. 64, no. 5, pp. 7. DOI: 10.1128/AAC.00399-20

17. Elfiky A.A. Ribavirin, remdesivir, sofosbuvir, galidesivir, and tenofovir against SARS-CoV-2 RNA dependent RNA polymerase (RdRp): a molecular docking study. Life Sci., 2020, vol. 15, no. 253, pp. 117592. DOI: $10.1016 /$ j.lfs.2020.117592

18. Li H., Wang Y.M., Xu J.Y., Cao B. Potential antiviral therapeutics for 2019 Novel Coronavirus. Chin. J. Tuberc. Respir. Dis., 2020, vol. 5, no. 43 (0), pp. E002. DOI: 10.3760/cma.j.issn.10010939.2020 .0002

19. Wang D., Hu B., Hu C., Zhu F., Liu X., Zhang J., Wang B., Xiang H. [et al.]. Clinical characteristics of 138 hospitalized patients with 2019 novel coronavirus-infected pneumonia in Wuhan, China. JAMA, 2020, vol. 17, no. 323 (11), pp. 1061-1069. https: //doi.org/10.1001/jama.2020. 1585 DOI: $10.1001 /$ jama.2020.1585

20. Arabi Y.M., Asiri A.Y., Assiri A.M., Jokhdar H.A.A., Alothman A., Balkhy H.H., Aljohani S., Al Harbi S. [et al.]. Treatment of Middle East respiratory syndrome with a combination of lopinavir/ritonavir and interferon- $\beta 1 \mathrm{~b}$ (MIRACLE trial): statistical analysis plan for a recursive two-stage group sequential randomized controlled trial. Trials, 2020, vol. 3, no. 21 (1), pp. 8. DOI: 10.1186/s13063-019-3846-x

21. Lim J., Jeon S., Shin H.Y., Kim M.J., Seong Y.M., Lee W.J., Choe K.W., Kang Y.M., Lee B., S.J. Park Case of the index patient who caused tertiary transmission of COVID-19 infection in Korea: the application of lopinavir/ritonavir for the treatment of COVID-19 infected pneumonia monitored by quantitative RT-PCR. J. Korean. Med. Sci., 2020, vol. 17, no. 35 (6), pp. e79. DOI: 10.3346/jkms.2020.35.e79

22. Wang M., Cao R., Zhang L., Yang X., Liu J., Xu M., Shi Z., Hu Z., Zhong W., Xiao G. Remdesivir and chloroquine effectively inhibit the recently emerged novel coronavirus (2019-nCoV) in vitro. Cell. Res., 2020, vol. 30, no. 3, pp. 269-271. DOI: 10.1038/s41422-020-0282-0

23. Jordan P.C., Stevens S.K., Deval J. Nucleosides for the treatment of respiratory RNA virus infections. Antivir. Chem. Chemother., 2018, vol. 26, pp. 1631083325. 
24. Cao Yu-C., Deng Q.-X., Dai S.-X. Remdesivir for severe acute respiratory syndrome coronavirus 2 causing COVID-19: An evaluation of the evidence. Travel Medicine and Infectious Disease, 2020, vol. 35, pp. 101647. DOI: 10.1016/j.tmaid.2020.101647

25. Dong L., Hu S., Gao J. Discovering drugs to treat coronavirus disease 2019 (COVID-19). Drug discoveries \& therapeutics, 2020, vol. 14, no. 1, vol. 58-60. DOI: 10.5582/ddt.2020.01012

26. Elfiky A.A. Anti-HCV, nucleotide inhibitors, repurposing against COVID-19. Life Sciences, 2020, vol. 1, no. 248, pp. 117477. DOI: 10.1016/j.lfs.2020.117477

27. Khamitov R.A., Loginova S., Shchukina V.N., Borisevich S.V., Maksimov V.A., Shuster A.M. Antiviral activity of arbidol and its derivatives against the pathogen of severe acute respiratory syndrome in the cell cultures. Vopr. Virusol., 2008, vol. 53, no. 4, pp. 9-13.

28. Wang Z., Chen X., Lu Y., Chen F., Zhang W. Clinical characteristics and therapeutic procedure for four cases with 2019 novel coronavirus pneumonia receiving combined Chinese and Western medicine treatment. Biosci. Trends., 2020, vol. 16, no. 14 (1), pp. 64-68. DOI: 10.5582/bst.2020.01030

29. Harrison C. Coronavirus puts drug repurposing on the fast track. Nature biotechnology, 2020, vol. 38, no. 4, pp. 389-381. DOI: 10.1038/d41587-020-00003-1

30. Chan K.W., Wong V.T., Tang S.C.W. COVID-19: An Update on the Epidemiological, Clinical, Preventive and Therapeutic Evidence and Guidelines of Integrative Chinese-Western Medicine for the Management of 2019 Novel Coronavirus Disease. Am. J. Chin. Med., 2020, vol. 48, no. 3, pp. 737-762. DOI: 10.1142/S0192415X20500378

31. Hellmich B., Agueda A., Monti S., Buttgereit F., de Boysson H., Brouwer E., Cassie R., Cid M.C. [et al.]. Update of the EULAR recommendations for the management of large vessel vasculitis. Ann. Rheum. Dis., 2020, vol. 79, no. 1, pp. 19-30. DOI: 10.1136/annrheumdis-2019-215672

32. Fanouriakis A., Kostopoulou M., Alunno A., Aringer M., Bajema I., Boletis J.N., Cervera R., Doria A. [et al.]. Update of the EULAR recommendations for the management of systemic lupus erythematosus. Ann. Rheum. Dis., 2019, vol. 78, no. 6, pp. 736-745. DOI: 10.1136/annrheumdis-2019-215089

33. Interim clinical guidance for management of patients with confirmed coronavirus disease (COVID-19). Centers for Disease Control and Prevention, 2020, pp. 13.

34. Shukla A.M., Shukla A.W. Expanding horizons for clinical applications of chloroquine, hydroxychloroquine, and related structural analogues. Drugs Context., 2019, vol. 25, no. 8, pp. 12. DOI: $10.7573 /$ dic.2019-9-1

35. Colson P., Rolain J.-M., Lagier J.-C., Brouqui P., Raoult D. Chloroquine and hydroxychloroquine as available weapons to fight COVID-19. Int. J. Antimicrob, 2020, vol. 55, no. 4, pp. 105932. DOI: $10.1016 /$ j.ijantimicag.2020.105932

36. Vincent M.J., Bergeron E., Benjannet S., Erickson B.R., Rollin P.E., Ksiazek T.G., Seidah N.G., Nichol S.T. Chloroquine is a potent inhibitor of SARS coronavirus infection and spread. Virol. J., 2005, no. 2, pp. 69. DOI: $10.1186 / 1743-422 X-2-69$

37. Multicenter collaboration group of Department of Science and Technology of Guangdong Province and Health Commission of Guangdong Province for chloroquine in the treatment of novel coronavirus pneumonia. Expert consensus on chloroquine phosphate for the treatment of novel coronavirus pneumonia. Zhonghua Jie He Не Hи Xi Za Zhi, 2020, vol. 20, no. 43, pp. E019.

38. Vademecum per la cura delle persone con malattia da COVID-19 - versione 2.02020. SIMIT Societa Italiana di Malattie Infettive e Tropicali Sezione regione Lombardia, 2020, 2 p.

39. Touret F., de Lamballerie X. Of chloroquine and COVID-19. Antiviral. Res., 2020, no. 177, pp. 104762. DOI: 10.1016/j.antiviral.2020.104762

40. Cortegiani A., Ingoglia G., Ippolito M., Giarratano A., Einav S. A systematic review on the efficacy and safety of chloroquine for the treatment of COVID-19. J. Crit. Care., 2020, no. 57, pp. 279-283. DOI: $10.1016 /$ j.jcrc.2020.03.005

41. Melles R.B., Marmor M.F. The risk of toxic retinopathy in patients on long-term hydroxychloroquine therapy. JAMA Ophthalmol, 2014, vol. 132, no. 12, pp. 1453-1460. DOI: 10.1001/jamaophthalmol.2014.3459

42. Sarma P., Kaur H., Kumar H., Mahendru D., Avti P., Bhattacharyya A., Prajapat M., Shekhar N. [et al.]. Virological and clinical cure in COVID-19 patients treated with hydroxychloroquine: 
A systematic review and meta-analysis. J. Med. Virol., 2020, vol. 92, no. 7, pp. 776-785. DOI: 10.1002/jmv. 25898

43. Gautret P., Lagier J., Parola P., Hoang V.T., Meddeb L., Mailhe M., Doudier B., Courjon J. [et al.]. Hydroxychloroquine and azithromycin as a treatment of COVID-19: results of an open-label non-randomized clinical trial. Int. J. Antimicrob. Agents, 2020, vol. 56, no. 1, pp. 105949. DOI: 10.1016/j.ijantimicag.2020.105949

44. Dilly S., Fotso Fotso A., Lejal N., Zedda G., Chebbo M., Rahman F., Companys S., Bertrand H.C. [et al.]. From naproxen repurposing to naproxen analogues and their antiviral activity against influenza A virus. J. Med. Chem., 2018, vol. 61, no. 16, pp. 7202-7217. DOI: 10.1021/acs.jmedchem.8b00557

45. Qiao W., Wang C., Chen B., Zhang F., Liu Y., Lu Q., Guo H., Yan C. [et al.]. Ibuprofen attenuates cardiac fibrosis in Streptozotocin-induced diabetic rats. Cardiology, 2015, vol. 131, no. 2, pp. 97-106. DOI: $10.1159 / 000375362$

46. Adnet F., Clama Schwok A. Efficacy of Addition of Naproxen in the Treatment of Critically Ill Patients Hospitalized for COVID-19 Infection (ENACOVID). ClinicalTrials.gov. Available at: https: //clinicaltrials.gov/ct2/show/NCT04325633 (12.05.2020).

47. Little P. Non-steroidal anti-inflammatory drugs and COVID-19. BMJ, 2020, no. 27, pp. 368 : m1185. DOI: 10.1136/bmj.m1185

48. Kotch C., Barrett D., Teachey D.T. Tocilizumab for the treatment of chimeric antigen receptor T cell-induced cytokine release syndrome. Expert review of clinical immunology, 2019, vol. 15, no. 8, pp. 813-822. DOI: 10.1080/1744666X.2019.1629904

49. Richardson P., Griffin I., Tucker C., Smith D., Oechsle O., Phelan A., Rawling M., Savory E., Stebbing J. Baricitinib as potential treatment for 2019-nCoV acute respiratory disease. Lancet, 2020, vol. 395, no. 10223, pp. e30-e31. DOI: 10.1016/S0140-6736 (20) 30304-4

50. Matsuyama S., Nao N., Shirato K., Kawase M., Saito S., Takayama I., Nagata N., Sekizuka T. [et al.]. Enhanced isolation of SARS-CoV-2 by TMPRSS2-expressing cells. Proceedings of the National Academy of Sciences, 2020, vol. 31, no. 117 (13), pp. 7001-7003. DOI: 10.1073/pnas.2002589117

51. Gordon D.E., Jang G.M., Bouhaddou M., Xu J., Obernier K., O’Meara M.J., Guo J.Z., Swaney D.L. [et al.]. A SARS-CoV-2-Human Protein-Protein Interaction Map Reveals Drug Targets and Potential Drug-Repurposing. BioRxiv, 2020, vol. 27, pp. 45. DOI: 10.1101/2020.03.22.002386

52. Farouka A., Salmanb S. Dapsone and doxycycline could be potential treatment modalities for COVID-19. Medical Hypotheses, 2020, no. 140, pp. 109768. DOI: 10.1016/j.mehy.2020.109768

53. Altschulera E.L., Kast R.E. Dapsone, colchicine and olanzapine as treatment adjuncts to prevent COVID-19 associated adult respiratory distress syndrome (ARDS). Medical Hypotheses, 2020, no. 141, pp. 109774. DOI: 10.1016/j.mehy.2020.109774

54. Zhang L., Liu Y. Potential interventions for novel coronavirus in China: a systematic review. Journal of medical virology, 2020, vol. 92, no. 5, pp. 479-490. DOI: 10.1002/jmv.25707

55. http://refhub.elsevier.com/S0889-1591(20)30589-4/h0330Grant W.B., Lahore H., McDonnell S.L., Baggerly C.A., French C.B., Aliano J.L., Bhattoa H.P. Evidence that vitamin D supplementation could reduce risk of influenza and COVID-19 infections and deaths. Nutrients, 2020, vol. 12, no. 4, pp. E988. DOI: 10.3390/nu12040988

56. Aranow C. Vitamin D and the immune system. J. Investig. Med., 2011, vol. 59, no. 6, pp. 881-886. DOI: 10.231/JIM.0b013e31821b8755

57. Nair R., Maseeh A. Vitamin D. The «sunshine» vitamin. J. Pharmacol Pharmacother, 2012, vol. 3, no. 2, pp. 118-126. DOI: 10.4103/0976-500X.95506

58. Kennel K.A., Drake M.T., Hurley D.L. Vitamin D deficiency in adults: when to test and how to treat. Mayo. Clin. Proc., 2010, vol. 85, no. 8, pp. 752-757. DOI: $10.4065 / \mathrm{mcp} .2010 .0138$

59. Nonnecke B., McGill J., Ridpath J., Sacco R.E., Lippolis J.D., Reinhardt T.A. Acute phase response elicited by experimental bovine diarrhea virus (BVDV) infection is associated with decreased vitamin D and E status of vitamin-replete preruminant calves. Journal of dairy science, 2014, vol. 97, no. 9 , pp. 5566-5579. DOI: 10.3168/jds.2014-8293 
60. Martineau A.R., Jolliffe D.A., Hooper R.L., Greenberg L., Aloia J.F., Bergman P., DubnovRaz G., Esposito S. [et al.]. Vitamin D supplementation to prevent acute respiratory tract infections: systematic review and meta-analysis of individual participant data. BMJ, 2017, vol. 15, no. 356, pp. i6583. DOI: $10.1136 / \mathrm{bmj} .16583$

61. Wimalawansa S.J. Reducing Risks from COVID-19: Cost-Effective Ways of Strengthening Individual's and the Population Immunity with Vitamin D. J. Endocrinol. Sci., 2020, vol. 2, no. 2, pp. $5-13$.

62. Lechien J.R., Chiesa-Estomba C.M., De Siati D.R., Horoi M., Le Bon S.D., Rodriguez A., Dequanter D., Blecic S. [et al.]. Olfactory and gustatory dysfunctions as a clinical presentation of mild-tomoderate forms of the coronavirus disease (COVID-19): a multicenter European study. Eur. Arch. Otorhinolaryngol, 2020, vol. 277, no. 8, pp. 2251-2261. DOI: 10.1007/s00405-020-05965-1

63. Doty R.L. Treatment for smell and taste disorders: a critical review. Handb. Clin. Neurol, 2019, no. 164, pp. 455-479. DOI: 10.1016/B978-0-444-63855-7.00025-3

Ashirmetov A.Kh., Mavlyanov I.R., Mavlyanov Z.I., Zharylkasynova G.Zh. COVID-19: well-known drugs, new opportunities. Health Risk Analysis, 2020, no. 4, pp. 169-178. DOI: 10.21668/health.risk/2020.4.19.eng

Received: 30.08 .2020

Accepted: 11.11.2020

Published: 30.12 .2020 